\section{Likely transmission of hepatitis $C$ virus through sharing of cutting and perforating instruments in blood donors in the State of Pará, Northern Brazil}

\author{
Possível transmissão do vírus da hepatite C \\ por compartilhamento de materiais cortantes e \\ perfurantes em doadores de sangue no Estado \\ do Pará, Norte do Brasil
}

Aldemir Branco de Oliveira-Filho 1 Adriana do Socorro Coelho Pimenta 2 Márcia de Fátima Maciel Rojas 2 Márcia Cristina Munhoz Chagas 2 Deborah Maia Crespo ${ }^{3}$ José Ângelo Barletta Crescente 4 José Alexandre Rodrigues de Lemos 1
1 Instituto de Ciências Biológicas, Universidade Federal do Pará, Belém, Brasil.

2 Fundação Centro de Hematologia e Hemoterapia do Pará, Belém, Brasil. ${ }_{3}^{3}$ Secretaria de Estado de Saúde Pública do Pará, Belém, Brasil.

4 Núcleo de Medicina Tropical, Universidade Federal do Pará, Belém, Brasil.

Correspondence J. A. R. Lemo Instituto de Ciências Biológicas, Universidade Federal do Pará. Av. Augusto Correa 1, Belém, PA 66075-110, Brasil. lemos@ufpa.br

\section{Abstract}

We determined the risk factors for HCV infection in blood donors in the State of Pará, Northern Brazil. We examined 256 blood donors seen at the Blood Bank of Pará State between 2004 and 2006. They were divided into two groups, depending on whether they were infected with HCV or not; 116 donors were infected with HCV, while the other 140 were free of infection. The HCV-RNA was detected by real-time PCR. All of the participants filled out a questionnaire about possible risk factors. The data were evaluated using simple and multiple logistic regressions. The main risk factors for HCV were found to be use of needles and syringes sterilized at home $(O R=4.55)$, invasive dental treatment $(O R=3.08)$, shared use of razors at home $(O R=1.99)$, sharing of disposable razors in barbershops, beauty salons, etc. $(O R=2.34)$, and sharing manicure and pedicure material $(O R=3.45)$. Local and regional health authorities should educate the public about sharing perforating and cutting materials at home, in barber/ beauty shops, and in dental clinics as risk factors for HCV infection.

Hepacivirus; Hepatitis C; Blood Donors

\section{Introduction}

Hepatitis C virus (HCV) is a major cause of acute and chronic hepatitis, cirrhosis, and hepatocellular carcinoma. It is estimated that $2 \%$ of the world population (approximately 123 million people) is infected with $\mathrm{HCV}$; most cases are asymptomatic and the victims are unaware that they have a viral infection 1,2 . HCV infection is a pandemic. Seroprevalence for HCV varies from less than $2 \%$ in some countries, such as Germany, India, France, and the United States, to high rates in countries and regions in Africa, Asia, and Europe, such as the Chinese province $\mathrm{Hu}$ bei $(30.13 \%)$, Mongolia (31.86\%), and in Egypt (28\%) 1,3. In South America, Brazil is estimated to have the highest HCV seroprevalence (1.6\%), which varies across different geographical regions ${ }^{4}$. Northern Brazil has the highest HCV seroprevalence $(2.12 \%)$, with a high frequency of genotype $14,5,6$. The various genotypes of HCV differ in their susceptibility to antiviral therapy, and evidence suggests a variation in clinical consequences, with patients with genotype 1 having the poorest prognosis 7,8. Epidemiological studies in the population of Brazilian blood donors have found similar results, with reported prevalences of anti-HCV from $0.38 \%$ to $2.6 \%$ and significant frequencies of genotype 16,9,10,11.

HCV is primarily transmitted via parenteral routes. Blood transfusions without previous testing for $\mathrm{HCV}$, and the reuse and the sharing 
of gloves, syringes, and other material that can become contaminated with blood in hospitals, clinics, emergency rooms, and doctors' offices are the most commonly documented routes of parenteral transmission of HCV 12,13,14. There are also other forms of transmission associated with parenteral procedures when contaminated equipment is used, such as intrafamilial transmission through sharing of razor blades or other perforating/cutting instruments 12,15,16,17. Transmission of HCV through sexual and perinatal routes has been reported, although both are relatively inefficient, except when HCV is associated with other microorganisms such as HIV and $\operatorname{HBV} 18,19$.

After HCV screening tests were added to the routine protocols of blood centers, and blood donors were screened clinically and epidemiologically based on knowledge of HCV transmission, the rate of post-transfusion hepatitis was significantly reduced 1,13,14. However, some cases of post-transfusion hepatitis $\mathrm{C}$ continue to be reported, because of the 4-20-week immunological window of HCV 20. Currently, the groups at risk of HCV infection are associated with frequent or inadequate parenteral procedures, such as: sharing syringes among drug users, sharing hemodialysis tubing and filters among patients with chronic kidney disease, multiple blood/hemoderivative transfusion in patients with chronic blood diseases, etc. Even with current knowledge of the various forms of HCV transmission, about $30 \%$ of cases are of unknown origin 13,14 .

In northern Brazil, there have been very few epidemiological studies of HCV infection ${ }^{5}$. In the State of Pará, the prevalence of anti-HCV ranges from $0.22 \%$ to $3.6 \%$, and it is predominantly found in individuals over 50 years old 21,22. Based on the scarcity of epidemiological information, we decided to determine the risk factors associated with transmission of HCV infection in blood donors in the State of Pará.

\section{Material and methods}

\section{Selection of blood donors}

This case-control epidemiological study was composed of HCV-infected and uninfected voluntary blood donors seen at the Fundação Centro de Hematologia e Hemoterapia do Pará (HEMOPA), northern Brazil. The blood donors were selected during routine blood collection at nine hematology and hemotherapy units and in blood-donation campaigns held in public and private institutions in Pará from January 1, 2004December 31, 2006 22. As is mandated by Brazil- ian law 23, all blood donations obtained at the HEMOPA were voluntary, anonymous, altruistic, and unremunerated, either directly or indirectly.

\section{Screening for HCV infection}

Plasma samples from all of the blood donors were screened for anti-HCV antibodies, using the Murex anti-HCV version 4.0 (Murex Biotech S.A., Kyalami, South Africa). Confirmation tests were done using real-time PCR (ABI Prism 7000, Applied Biosystems, Foster City, U.S.A.). The viral RNA was extracted using the QIAmp Viral RNA Mini Kit (Qiagen). Molecular diagnosis was accomplished by detecting the nucleotide fragment (67 bp) of 5' UTR with the TaqMan EZ RT-PCR Core Reagents kit (Applied Biosystems), according to the manufacturer's instructions, adding the primers (5' 3': CGCTCAATGCCTGGAGATTT and TTTCGCGACCCAACACTACTC) and the probe (5' 3':FAM-TGCCCCCGCAAGACTGCTAGCTAMRA). The amplification conditions were: 1 cycle: $50^{\circ} \mathrm{C} / 2 \mathrm{~min}, 60^{\circ} \mathrm{C} / 30 \mathrm{~min}$, and $95^{\circ} \mathrm{C} / 5$ min; 50 cycles: $94^{\circ} \mathrm{C} / 20 \mathrm{~s}$ and $60^{\circ} \mathrm{C} / 1 \mathrm{~min}$. Nucleic acid tests (NAT) directly detect the presence of HCV RNA, using a combination of amplification and detection techniques. In general, NAT are quite sensitive and specific. HCV RNA can be detected one to three weeks after infection, approximately one month before the appearance of antibodies 24,25 .

\section{Risk factors}

The participants completed a questionnaire about possible risk factors for infection with HCV. This questionnaire included questions about age, use of home-sterilized needles and syringes, use of illicit drugs, blood transfusion before or after 1993 , surgery before or after 1993, use of condoms during sexual intercourse, more than five sex partners during the previous year, invasive dental treatment (root canal and surgical tartar removal), shared use of razors at home, shared use of disposable razors in public places (beauty salons, barber shops, etc.), and shared use of instruments for manicures and pedicures.

\section{Statistical analysis}

Each possible risk factor for HCV infection (as diagnosed by molecular analysis) was analyzed separately, by simple logistic regression. All the potential risk factors with probabilities of $\mathrm{p} \leq 0.2$ were examined and included in the final model of HCV transmission using backward stepwise multiple logistic regression. A multiple logistic regression was then run to determine the asso- 
ciation of each risk factor with HCV infection, as diagnosed by molecular analysis. Various possible types of interactions were evaluated in order to determine how they might improve the final model 26. The fit of the final model was assessed using the Hosmer-Lemeshow goodness-of-fit test 27 . Finally, the risk factors listed by multiple logistic regression were quantified and evaluated by the chi-square test, with expected equal proportions as the criterion to distinguish between infected and uninfected groups. All statistical analyses were carried out in duplicate with the programs BioEstat version 5.0 (Sociedade Civil Mamirauá, Manaus, Brazil) 28 and PASW Statistic version 18.0 (SPSS Inc., Chicago, U.S.A.); except that the Hosmer-Lemeshow test was performed only by PASW Statistic.

\section{Ethics}

This study was approved by the Research Ethics Committee of the Tropical Medicine Center at the Federal University of Pará, Brazil. All the blood donors were informed about the objectives of the research and gave their written informed consent to participate in this study.

\section{Results}

From 2004-2006, the HEMOPA attended 242,726 voluntary blood donors in the State of Pará. HCV RNA was detected in 304 of these donors (antiHCV antibody-positive or indeterminate). All of the 304 infected donors were invited to participate in this study, and 116 agreed to participate 22 . In addition, we invited 304 uninfected blood donors (anti-HCV antibody-negative and HCV RNA-negative), randomly selected from 241,614 uninfected donors, to participate as a control group 22; 140 of them visited the HEMOPA to complete the epidemiological questionnaire. In this way, we selected a total of 256 blood donors in Pará to participate in the research.

These blood donors were divided into two groups, based on detection of anti-HCV antibodies and HCV RNA. The numerical relationship between the case and control groups was approximately 1:1 (116:140; no statistical difference in the sample size; $\chi^{2}=2.25 ; \mathrm{p}=0.134$ ). The case group consisted of 116 blood donors infected with HCV (anti-HCV antibody-positive or indeterminate, and HCV RNA-positive). The control group consisted of 140 uninfected blood donors (anti-HCV antibody-negative and HCV RNA-negative). Age appeared to be a risk factor for infection with HCV. In the infected donor group, the median age was 40 years, whereas it was 30 years in the uninfected blood donors. Blood donors over 35 years of age were significantly more likely to be infected than those under 35 (Table 1); this information should be considered in the construction of an epidemiological model for HCV transmission.

Other factors associated with the molecular diagnosis of infection were "use of needles and/ or syringes at home", "blood transfusion", "invasive dental treatment (root canal or surgical tartar removal)", "sharing of razors at home", "using disposable blades in public places (beauty salons, barber shops, or similar establishments)", "shared use of manicure and pedicure instruments", and "use of illicit drugs (injectable or non-injectable)" (Table 1). However, it was not possible to determine precisely which factors significantly contributed to HCV transmission, by means of univariate analysis (Table 2). We found that $85.39 \%$ of the blood donors infected by HCV had $1-5$ risk factors, and $87.15 \%$ of the uninfected blood donors had 0-3 risk factors.

We then used multiple logistic regression to determine which risk factors significantly contributed to HCV transmission (Table 3). The importance (odds ratio) of these risk factors was 4.55 for "use of needles and/or syringes at home", 3.08 for "invasive dental treatment (root canal or surgical tartar removal)", 1.99 for "sharing of razors at home", 2.34 for "shared use of disposable blades in public places (beauty salons, barber shops, or similar establishments)", and 3.45 for "shared use of manicure and pedicure instruments" (Table 3). The Hosmer-Lemeshow goodness-of-fit test showed a good fit for the final model $\left(\chi^{2}=\right.$ $2,734, \mathrm{p}=0.950$ ). We see in Table 4 that $55.17 \%$ of the blood donors infected with HCV had 3-5 risk factors, whereas $87.15 \%$ of the uninfected blood donors had 0-2 risk factors, based on multiple logistic regression. Most of the infected donors had three or more risk factors $\left(\chi^{2}=69.246\right.$; $\mathrm{p}<0.001$ ). The epidemiological model for HCV transmission in blood donors in Pará included five parenteral risk factors, with sharing perforating/cutting materials in the home and invasive dental treatment being the most important.

\section{Discussion}

In this study, the final model of HCV transmission based on multiple logistic regression showed that the use of home-sterilized needles and glass syringes, invasive dental treatments, shared use of razors at home, shared use of disposable razors in beauty salons, barber shops, and similar establishments, and shared use of manicure and pedicure material should be taken into account 
Table 1

Initial discrimination of risk factors for HCV infection using simple logistic regression (molecular diagnosis versus risk factor).

\begin{tabular}{|c|c|c|c|c|}
\hline Risk factors for HCV infection & $\mathrm{n}$ & HCV RNA (\%) & Odds ratio & $95 \% \mathrm{Cl}$ \\
\hline \multicolumn{5}{|l|}{ Gender } \\
\hline Male & 180 & $85(47)$ & 1.30 & $0.75-2.24$ \\
\hline Female & 76 & $39(51)$ & 1.00 & \\
\hline \multicolumn{5}{|l|}{ Marital status } \\
\hline Single & 98 & $38(39)$ & 1.00 & $0.99-2.76$ \\
\hline Married & 158 & $79(50)$ & 1.65 * & \\
\hline \multicolumn{5}{|l|}{ Age (years) } \\
\hline$>35$ & 132 & $77(76)$ & $3.05 * \star$ & $1.83-5.10$ \\
\hline$\leq 35$ & 124 & $39(31)$ & 1.00 & \\
\hline \multicolumn{5}{|c|}{ Use of needles and/or syringes sterilized at home } \\
\hline Yes & 70 & $53(72)$ & 6.09 ** & $3.26-11.37$ \\
\hline No & 186 & $63(33)$ & 1.00 & \\
\hline \multicolumn{5}{|l|}{ Recipient of a blood transfusion } \\
\hline Yes & 49 & $30(61)$ & 2.22 ** & $1.17-4.20$ \\
\hline No & 207 & $86(42)$ & 1.00 & \\
\hline \multicolumn{5}{|c|}{ Recipient of a blood transfusion prior to 1993 *** } \\
\hline Yes & 20 & $13(65)$ & 1.18 & $0.35-3.94$ \\
\hline No & 29 & $17(59)$ & 1.00 & \\
\hline \multicolumn{5}{|l|}{ Had surgery } \\
\hline Yes & 117 & $58(50)$ & 1.37 & $0.84-2.25$ \\
\hline No & 139 & $58(48)$ & 1.00 & \\
\hline \multicolumn{5}{|l|}{ Had surgery prior to 1993 \# } \\
\hline Yes & 53 & $31(58)$ & 1,69 & $0.79-3.65$ \\
\hline No & 64 & $27(42)$ & 1.00 & \\
\hline \multicolumn{5}{|l|}{ Has a tattoo } \\
\hline Yes & 37 & $22(59)$ & $1.95 *$ & $0.96-3.96$ \\
\hline No & 219 & $94(43)$ & 1.00 & \\
\hline \multicolumn{5}{|c|}{ Use of condoms during the sexual act } \\
\hline No & 157 & $77(49)$ & 1.48 * & $0.89-2.47$ \\
\hline Yes & 99 & 39 (39) & 1.00 & \\
\hline \multicolumn{5}{|c|}{ More than five sexual partners during the previous year } \\
\hline Yes & 50 & $27(54)$ & 1.54 * & $0.83-2.87$ \\
\hline No & 206 & $89(43)$ & 1.00 & \\
\hline \multicolumn{5}{|c|}{ Invasive dental treatment (canal work and tartar surgery) } \\
\hline Yes & 126 & $70(56)$ & 2.28 ** & $1.38-3.77$ \\
\hline No & 130 & $46(35)$ & 1.00 & \\
\hline \multicolumn{5}{|l|}{ Sharing razors at home } \\
\hline Yes & 94 & $56(60)$ & 2.51 ** & $1.49-4.22$ \\
\hline No & 162 & $60(37)$ & 1.00 & \\
\hline \multicolumn{5}{|c|}{ Shared use of disposable blades in public places } \\
\hline \multicolumn{5}{|c|}{ (beauty salons, barber shops and similar) } \\
\hline Yes & 162 & $59(36)$ & 1.00 & $1.59-4.54$ \\
\hline No & 94 & $57(61)$ & $2.67 * *$ & \\
\hline \multicolumn{5}{|c|}{ Use of shared instruments for manicure and pedicure } \\
\hline Yes & 134 & $41(31)$ & 1.00 & $2.16-6.07$ \\
\hline No & 122 & $75(61)$ & $3.62 * *$ & \\
\hline \multicolumn{5}{|c|}{ Use of illicit drugs (injectable or not) } \\
\hline Yes & 28 & $18(64)$ & $2.39 * *$ & $1.06-5.40$ \\
\hline No & 228 & $98(43)$ & 1.00 & \\
\hline
\end{tabular}

${ }^{*} p<0.05$

** $p \leq 0.2$

*** Dependent sample numbers or altered by specific factors: 49

\# Dependent sample numbers or altered by specific factors: 117 . 
Table 2

Division of blood donors into groups according to the number of significant risk factors for HCV infection, based on univariate analysis.

\begin{tabular}{lcccc}
\hline $\begin{array}{l}\text { Number of risk } \\
\text { factors }\end{array}$ & \multicolumn{2}{c}{ Infected } & \multicolumn{2}{c}{ Uninfected } \\
& $\mathbf{n}$ & $\%$ & $\mathbf{n}$ & $\%$ \\
\hline 0 & 1 & 0.86 & 14 & 10.00 \\
1 & 7 & 6.03 & 43 & 30.72 \\
2 & 20 & 17.24 & 38 & 27.14 \\
3 & 22 & 18.97 & 27 & 19.29 \\
4 & 29 & 25.00 & 12 & 8.57 \\
5 & 21 & 18.11 & 5 & 3.57 \\
6 & 11 & 9.48 & 1 & 0.71 \\
7 & 4 & 3.45 & 0 & 0.00 \\
8 & 1 & 0.86 & 0 & 0.00 \\
\hline
\end{tabular}

by local and regional health authorities and by those of other countries with cultures similar to that of northern Brazil, in order to inform political and public strategies to control HCV transmission. The detection and treatment of HCV-infected patients are essential public-health measures for containing viral transmission. However, public awareness about the risks of specific actions also significantly contributes to reducing prevalence and to the prevention of new infections 29,30 . The risk factors that we examined are parenteral procedures that can be avoided if the population is aware of the risks of transmitting microorganisms. Shaving or trimming nails can generate trauma or microtrauma on the skin surface, resulting in exposure to HCV on blades or nail scissors contaminated by asymptomatic infected family members or by other people who are unknowingly infected and who frequent barbershops and beauty salons. In Italy, Pakistan, and Nigeria, HCV transmission by sharing razor blades and other cutting instruments, as well as other forms of viral dissemination due to a lack of public awareness, have been reported as risk factors for infection 12,31,32.

The final HCV transmission model indicates that the use of home-sterilized needles and glass syringes is the greatest risk factor for infection among blood donors in Pará. In Brazil, disposable perforating and cutting materials for health procedures began to be used on a large scale during the second half of the 1980s. This situation, together with a lack of knowledge about HCV transmission, likely accounts for infection being more common among blood donators over 35 , since transmission could have occurred through sharing of inadequately sterilized syringes and needles in homes with individuals who were asymptomatic and unaware that they were infected. Administering injectable medication without adequately sterilizing syringes or needles has been the main cause of HCV transmission worldwide, especially in developing countries 2,15,33. Probably the risk factor "use of home-sterilized syringes and needles" was partly responsible for the significantly higher infection rate in the group older than 35 years. This may also indicate that longer exposure to risk factors increases the probability of infection with HCV.

The use of illicit injectable or non-injectable drugs is currently considered as the most important risk factor for HCV 1,2,32. However, we did not find it to be a significant factor in our study. Probably this was because of the clinical/epidemiological preselection of blood donors by the HEMOPA, which considers the use of illicit drugs as an exclusion factor for blood donation. However, we still detected 28 blood donors who were illicit drug users; they had withheld information during the selection process in order to obtain free blood tests.

We found invasive dental treatment (root canals and surgical removal of tartar) to be a risk factor for HCV infection. Various studies have detected HCV RNA in the saliva of HCV-infected patients 34,35 . Consequently, HCV in the saliva, combined with inadequate sterilization of odontological instruments, could be a means of HCV transmission. Nosocomial transmission could be investigated in greater detail through phylogenetic analysis of the viral strains circulating among those patients in our study who apparently had been infected during dental treatment. In this study, the high odds ratio (3.08) and the narrow 95\% confidence interval (1.68-5.65) indicate the high probability of this type of event.

Various studies have recognized blood transfusion as a significant risk factor for HCV infection 13,30. However, this was not found in our study. The univariate analysis indicated a significant risk from blood transfusion. However, it was not a significant factor in the model constructed based on multiple regression analysis. Probably this was due to the influence of other factors that increased the apparent significance of receiving blood transfusions. Transmission of HCV infection by blood transfusion was significantly reduced by the introduction of HCV tests for screening blood donors ${ }^{14}$, which is the case in the Pará state blood bank. The rate of post-transfusion hepatitis $\mathrm{C}$ infection remains very high in countries in which HCV screening is deficient or nonexistent 13,14,36. 
Risk factors for HCV infection in blood donors in the State of Pará based on multiple logistic regression.

\begin{tabular}{|c|c|c|c|c|}
\hline Risk factors for HCV infection & $\mathbf{n}$ & HCV RNA (\%) & Odds ratio * & $95 \% \mathrm{Cl}$ \\
\hline \multicolumn{5}{|l|}{ Use of needles and syringes } \\
\hline \multicolumn{5}{|l|}{ sterilized at home } \\
\hline Yes & 70 & $53(72)$ & 4.55 & $2.28-9.10$ \\
\hline No & 186 & $63(33)$ & 1.00 & \\
\hline \multicolumn{5}{|l|}{ Invasive dental treatment } \\
\hline \multicolumn{5}{|l|}{ (canal work and tartar removal) } \\
\hline Yes & 126 & $70(56)$ & 3.08 & $1.68-5.65$ \\
\hline No & 130 & $46(35)$ & 1.00 & \\
\hline \multicolumn{5}{|l|}{ Shared use of razors at home } \\
\hline Yes & 94 & $56(60)$ & 1.99 & $1.08-3.66$ \\
\hline No & 162 & $60(37)$ & 1.00 & \\
\hline \multicolumn{5}{|c|}{ Shared use of disposable razors in a } \\
\hline \multicolumn{5}{|c|}{ public place (beauty salons and barber shops) } \\
\hline Yes & 162 & $59(36)$ & 1.00 & $1.26-4.32$ \\
\hline No & 94 & $57(61)$ & 2.34 & \\
\hline \multicolumn{5}{|c|}{ Shared use of manicure and pedicure instruments } \\
\hline Yes & 134 & $41(31)$ & 1.00 & $1.88-6.33$ \\
\hline No & 122 & 75 (61) & 3.45 & \\
\hline
\end{tabular}

$* p<0.05$

Table 4

Infected and uninfected blood donors grouped according to the number of risk factors, based on multiple regression analysis.

\begin{tabular}{lccccc}
\hline \multirow{2}{*}{ Number of risk factors } & \multicolumn{2}{c}{ Infected } & \multicolumn{2}{c}{ Non-infected } \\
& $\mathbf{n}$ & $\%$ & $\mathbf{n}$ & $\%$ \\
\hline 0 & 1 & 0.86 & 25 & 17.86 \\
1 & 20 & 17.24 & 56 & 40.00 \\
2 & 31 & 26.72 & 41 & 29.29 \\
3 & 36 & 31.03 & 16 & 11.43 \\
4 & 19 & 16.38 & 1 & 0.71 \\
5 & 9 & 7.76 & 1 & 0.71 \\
\hline
\end{tabular}

We propose here an HCV transmission model for blood donors in Pará, based on the use of home-sterilized needles and/or syringes, invasive dental treatment (root canal or surgical tartar removal), sharing of razors at home, shared use of disposable razors in public places (beauty salons, barber shops, or similar establishments), and shared use of manicure and pedicure instruments. This information should help to inform political and public strategies of local and regional heath authorities to help control the transmission of HCV infection in the state of Pará, through public awareness of the risk of HCV infection due to sharing perforating and cutting instruments at home, in beauty salons and barber shops, and in dental clinics. 


\section{Resumo}

Nós determinamos os fatores de risco à infecção pelo HCV em doadores de sangue no Estado do Pará, Brasil. Foram analisados 256 doadores de sangue atendidos na Fundação HEMOPA de 2004 a 2006, sendo divididos em dois grupos: infectados e não-infectados. $O$ diagnóstico foi realizado por PCR em tempo real. Todos os participantes responderam a questionário sobre possiveis fatores de risco, sendo a modelagem estatística feita por regressão logística simples e múltipla. Os fatores de risco à infecção foram: uso de agulhas e seringas de vidros esterilizadas em casa $(O R=4,55)$, re alização de tratamento dentário invasivo $(O R=3,08)$, compartilhamento de lâminas em domicílio $(\mathrm{OR}=$ 1,99), compartilhamento de lâminas descartáveis em barbearias, salões de beleza $(\mathrm{OR}=2,34)$, e compartilhamento de material de manicure e pedicure $(\mathrm{OR}=$ $3,45)$. As autoridades de saúde devem conscientizar a população sobre o compartilhamento de materiais perfuro-cortantes em domicílio, salões de beleza e consultórios dentários como fatores de risco à infecção.

Hepacivirus; Hepatite C; Doadores de Sangue

\section{Contributors}

J. A. R. Lemos contributed to the study design, data interpretation, and the corrections to the manuscript. A. B. Oliveira-Filho contributed to the study design, molecular data acquisition, data analysis and interpretation, and manuscript preparation. A. S. C. Pimenta contributed to the study design, molecular data acquisition and manuscript preparation. M. F. M. Rojas, M. C. M. Chagas, D. M. Crespo and J. Â. B. Crescente were responsible for data collection, data interpretation and corrections to the manuscript.

\section{Acknowledgments}

We wish to thank Dr. M. Sidia Callegari-Jacques (Biosciences Institute, Federal University of Rio Grande do Sul, Brazil) and Dr. Manuel Ayres (Institute of Biological Sciences, Federal University of Pará, Brazil) for support and suggestions concerning the statistical analyses of this study.

This work was supported by grants from the Programa Nacional de DST/AIDS/Hepatites (CSV298/2007), Ministry of Health, co-supported by former Secretaria de Estado de Ciência, Tecnologia e Meio-Ambiente do Pará (current Secretaria de Estado de Desenvolvimento, Ciência e Tecnologia do Pará), and scholarships provided by CNPq, Brazil.

\section{References}

1. Shepard CW, Finelli L, Alter MJ. Global epidemiology of hepatitis C virus infection. Lancet Infect Dis 2005; 5:558-67.

2. Alter MJ. Epidemiology of hepatitis C virus infection. World J Gastroenterol 2007; 13:2436-41.

3. Lo Re 3rd V, Kostman JR. Management of chronic hepatitis C. Postgrad Med J 2005; 81:376-82.

4. Grupo de Estudo da Sociedade Brasileira de Hepatologia. Epidemiologia da infecção pelo vírus da hepatite C no Brasil. Gastroenterol End Digest 1999; 18:S3-8.

5. Da Fonseca JCF, Brasil LM. Hepatitis C virus infection in the Amazon Brazilian region. Rev Soc Bras Med Trop 2004; 37:1-8.

6. Campiotto S, Pinho JR, Carrilho FJ, Da Silva LC, Souto FJ, Spinelli V, et al. Geographic distribution of hepatitis C virus genotypes C in Brazil. Braz J Med Biol Res 2005; 38:41-9.
7. Hadziyannis SJ, Koshina, JS. Differences in epidemiology, liver disease and treatment response among HCV genotypes. Hepatol Res 2004; 29:129-35.

8. Zeuzem S. Heterogeneous virologic response rates to interferon-based therapy in patients with chronic hepatitis C: who responds less well. Ann Intern Med 2004; 140:370-81.

9. Gonçalves FL, Boccato RSBS, Pedro RJ, Papaiordanou PMO, Souza CA, Gonçalves NSL, et al. Prevalence of HBsAg, anti-HBc and anti-HCV in blood donors of "Hemocentro-Campinas". Rev Inst Med Trop São Paulo 1993; 35:45-51.

10. Narciso-Schiavon JL, Schiavon LL, Carvalho-Filho RJ, Freire FCF, Cardoso JR, Bordin JO, et al. Antihepatitis $\mathrm{C}$ virus-positive blood donors: are women any different? Transfus Med 2008; 18:175-83. 
11. Nascimento MC, Mayaud P, Sabino EC, Torres KL, Franceschi S. Prevalence of hepatitis B and C serological markers among first-time blood donors in Brazil: a multi-center serosurvey. J Med Virol 2008; 80:53-7.

12. Bari A, Akhtar S, Rahbar MH, Luby SP. Risk factors for hepatitis $\mathrm{C}$ virus infection in male adults in Rawalpindi-Islamabad, Pakistan. Trop Med Int Health 2001; 6:732-8.

13. Memon MI, Memon MA. Hepatitis C: an epidemiological review. JViral Hepat 2002; 9:84-100.

14. Prati, D. Transmission of hepatitis $C$ virus by blood transfusions and other medical procedures: a global review. J Hepatol 2006; 45:607-16.

15. Kane M. Unsafe injections. Bull World Health Organ 1998; 76:99-100.

16. Marx MA, Murugavel KG, Sivaram S, Balakrishnan P, Steinhoff M, Anand S, et al. The association of health care use and hepatitis $C$ virus infection in a random sample of urban slum community residents in southern India. Am J Trop Med Hyg 2003; 68:258-62.

17. Hauri AM, Armstrong GL, Hutin YJF. The global burden of disease attributable to contaminated injections given in health care settings. Int J STD AIDS 2004; 15:7-16.

18. Conte D, Fraquelli M, Prati D, Colucci A, Minola E. Prevalence and clinical course of chronic hepatitis $\mathrm{C}$ virus (HCV) infection and rate of HCV vertical transmission in a cohort of 15.250 pregnant women. Hepatology 2000; 31:751-5.

19. Gibb DM, Goodall RL, Dunn DT, Healy M, Neave P, Cafferkey M, et al. Mother-to-child transmission of hepatitis $C$ virus: evidence for preventable peripartum transmission. Lancet 2000; 356:904-7.

20. Strauss E. Hepatitis C. Rev Soc Bras Med Trop 2001; 34:69-82.

21. Aquino JA, Pegado KA, Barros LP, Machado LFA. Seroprevalence of hepatitis B virus and hepatitis $C$ virus infections among individuals in the State of Pará. Rev Soc Bras Med Trop 2008; 41:334-7.

22. Oliveira-Filho AB, Pimenta ASC, Rojas MFM, Chagas MCM, Crescente JAB, Crespo DM, et al. Prevalence and genotyping of hepatitis $\mathrm{C}$ virus in blood donors in the state of Pará, Northern Brazil. Mem Inst Oswaldo Cruz 2010; 105:103-6.

23. Agência Nacional de Vigilância Sanitária/Ministério da Saúde. Resolução RDC nº. 153. http://e-legis. bvs.br/leisref/public/showAct.php?mode=PRINT_ VERSION\&id=11662 (accessed on 07/Apr/2008).
24. Scott JD, Gretch DR. Molecular diagnostics of hepatitis $\mathrm{C}$ virus infection. A systematic review. JAMA 2007; 297:724-32.

25. Garcia FB, Gomide GPM, Pereira GA, MoraesSouza H. Importance of screening and confirmatory tests to detect blood donors infected by the hepatitis C virus. Rev Bras Hematol Hemoter 2008; 30:218-22.

26. Bruzzi P, Green SB, Byar DP, Brinton LA, Schairer C. Estimating the population attributable risk for multiple risk factors using case-control data. Am J Epidemiol 1985; 122:904-14.

27. Hosmer DW, Lemeshow S. Applied logistic regression. 2nd Ed. New York: John Wiley \& Sons; 2000.

28. Ayres M, Ayres Jr. M, Ayres DL, Santos ASS. BioEstat 5.0: aplicações estatísticas nas áreas das ciências biológicas e médicas [CD-ROM]. Belém: Sociedade Civil Mamirauá/Brasília: Conselho Nacional de Desenvolvimento Científico e Tecnológico; 2005.

29. Lavanchy D. The global burden of hepatitis C. Liver Int 2009; 29:S74-81.

30. Wasley A, Alter MA. Epidemiology of hepatitis C: geographic differences and temporal trends. Semin Liver Dis 2001; 20:1-16.

31. Mele A, Corona R, Tosti ME, Palumbo F, Moiraghi A, Novaco F, et al. Beauty treatments and risk of parenterally transmitted hepatitis. Results from the hepatitis surveillance system in Italy. Scand J Infect Dis 1995; 27:441-4.

32. Koate BBD, Buseri FI, Jeremiah ZA. Seroprevalence of hepatitis $\mathrm{C}$ virus among blood donors in Rivers State, Nigeria. Transfus Med 2005; 15:449-51.

33. Reeler AV. Injections: a fatal attraction. Soc Sci Med 1990; 31:1119-25.

34. Arrieta JJ, Rodriguez-Inigo E, Casqueiro M, Bartolomé J, Manzarbeitia F, Herrero M, et al. Detection of hepatitis $\mathrm{C}$ virus replication by in situ hybridization in epithelial cells of anti-hepatitis $C$ virus-positive patients with and without oral lichen planus. Hepatology 2000; 32:97-103.

35. Hermida M, Ferreiro MC, Barral S, Laredo R, Castro A, Diz Dios P. Detection of HCV RNA in saliva of patients with hepatitis $C$ virus infection by using a highly sensitive test. J Virol Methods 2002; 101:29-35.

36. Madhava V, Burgess C, Drucker E. Epidemiology of chronic hepatitis $\mathrm{C}$ virus infection in sub-Saharan Africa. Lancet Infect Dis 2002; 2:293-302.

Submitted on 18/Apr/2009

Final version resubmitted on $04 / \mathrm{Feb} / 2010$

Approved on 01/Mar/2010 